\title{
ITALIAN GEOLOGY AND CLIMATE CHANGE IN THE DEEP PAST
}

\author{
Nota del m.s. HUGH C. JENKYNS (*)
}

(Adunanza del 25 ottobre 2018)

SunTO. - Le rocce sedimentarie mesozoiche, depositatesi in mare sia profondo che poco profondo, sono presenti in tutta Italia e ben esposte nelle montagne e nelle valli fluviali. Studi dettagliati di queste successioni da parte di geologi italiani, a partire dal diciannovesimo secolo e continuando fino ad oggi, hanno prodotto una biostratigrafia ad alta risoluzione che consente di identificare incrementi di tempo geologico inferiori a un milione di anni. I primi lavori si basavano in gran parte sulle ammoniti per definire la biostratigrafia, ma erano applicabili principalmente ai sedimenti di età giurassica. Lo studio di calcari pelagici e di scisti di età cretacea furono successivamente, nel ventesimo secolo, studiati usando microfossili planctonici, con dimensioni di un granello di sabbia, e anche nannofossili ancora più piccoli di scala micrometrica. Il lavoro pioneristico sulla magnetostratigrafia e la ciclostratigrafia, svolto principalmente sui sedimenti cretacei che affiorano in Marche-Umbria, ha aggiunto ulteriore raffinamento alla misurazione di brevi intervalli di tempo rappresentati nelle rocce. Con questa base stratigrafica, segnali litologici e chimici distinti, scoperti per primi nelle sequenze italiane, sono stati riconosciuti in tutto il mondo e dimostrati di rilevanza globale. In particolare, il coinvolgimento degli isotopi del carbonio ha sottolineato l'utilità della chemostratigrafia, non solo come ulteriore aiuto alla correlazione, ma anche come testimonianza di importanti cambiamenti ambientali. Più significativi in questo contesto sono gli eventi anossici oceanici cretacei, la cui documentazione sedimentaria è stata documentata per la prima volta in Italia. Questi eventi sono stati caratterizzati dallo sviluppo di scisti neri ricchi di sostanza organica depositati in acque in gran parte prive di ossigeno durante periodi di temperature straordinariamente elevate note come 'ipertermali'. Gli ipertermali, probabilmente guidati da emissioni di anidride carbonica da eruzioni vulcaniche su larga scala, illustrano l'impatto ambientale su un pianeta colpito da un riscaldamento globale estremo.

(*) Department of Earth Sciences, University of Oxford, South Parks Road, Oxford, UK. E-mail: hugh.jenkyns@earth.ox.ac.uk 
ABSTRACT. - Mesozoic sedimentary rocks, of both deep- and shallow-water character, are present throughout Italy and well exposed in mountains and river valleys. Detailed studies of these sections by Italian geologists, beginning in the nineteenth century and continuing to this day, have produced a high-resolution biostratigraphy that allows identification of increments of geological time of less than a million years. Early work relied largely on ammonites to define biostratigraphy but was applicable primarily to sediments of Jurassic age. Study of deep-marine pelagic limestones and shales of Cretaceous age were subsequently, in the twentieth century, investigated using planktonic microfossils, the size of a sand grain, and even smaller nannofossils of micron scale. Pioneering work on magnetostratigraphy and cyclostratigraphy, undertaken primarily on Cretaceous sediments cropping out in Marche-Umbria, added further refinement to the measuring of small intervals of time in rock. With this stratigraphic background, distinct lithological and chemical signals, discovered first in Italian sequences, could be recognized world-wide and proven to be of global significance. In particular, the involvement of carbon isotopes has underscored the utility of chemostratigraphy, not only as a further aid to correlation, but also as a testimonial to major environmental change. Most significant in this context are the Cretaceous oceanic anoxic events, whose sedimentary record was first documented from Italy. These events were characterized by the development of organic-rich black shales deposited in waters largely lacking in oxygen during times of extraordinarily high temperatures known as hyperthermals. Hyperthermals, likely driven by supply of carbon dioxide from large-scale volcanic eruptions, illustrate the environmental impact on a planet affected by extreme global warming.

\section{INTRODUCTION}

As a natural laboratory for the earth sciences, the sedimentary rocks of Mesozoic age (Triassic, Jurassic and Cretaceous Periods) exposed in the Italian peninsula and Sicily are unrivalled. Our understanding of the chemistry and biology of ancient oceans and seas that existed in and around the Mediterranean area over the period $\sim 252$ to $\sim 66$ million years ago has been facilitated by the presence of exquisite exposures of limestones and shales in mountains and river valleys stretching from the Alps south to the Apennines and beyond. This interval is commonly considered as representing a time when the Earth was a so-called 'greenhouse world' when the planet was largely or completely without ice at the poles.

\subsection{Ammonites and biostratigraphy}

Early studies on these Mesozoic sedimentary rocks, undertaken in the nineteenth century by Italian geologists, were primarily palaeonto- 
logical in nature and were essential in laying the groundwork for our understanding of the stratigraphy of the different successions. Ammonites were a particular attraction to these early workers, many of whom built up substantial collections of these fossils that would be impossible to duplicate today [1]. Most ammonites came from pelagic sedimentary rocks of Jurassic age, being particularly common in the socalled rosso ammonitico, a much-quarried brick-red decorative marble used in palaces, churches and other buildings throughout the world. However, ammonites are relatively rare in both the older Triassic and the younger Cretaceous deposits in Italy and elsewhere in the Alpinemediterranean region.

\subsection{Microfossils, nannofossils and biostratigraphy}

The study of planktonic microfossils such as foraminifera, typically the size of a sand grain, accelerated in the twentieth century, to be followed by identification and classification of even smaller micron-sized nannofossils known as coccoliths. These fossils facilitated the dating and stratigraphical resolution of these younger Mesozoic (i.e. Cretaceous) pelagic sediments to a level comparable to that achieved by ammonites [e.g. 2, 3, 4, 5]. Much of this work, spear-headed in Italy, used optical microscopy to study thin-sections and smear-slides taken from consolidated material. Some limestone outcrops, particularly those exposing the Scaglia, so called because of its tendency to break into flakes when hit with a hammer, also contained a record of reversals in the Earth's magnetic field that were an additional aid to stratigraphy and correlation $[6,7,8]$. By the nineteen-seventies, the stage was set for telling accurate time in sedimentary rocks and identifying increments of millions of years or less, in many cases with the primary localities situated in the Alps and Apennines. Furthermore, the same increments of geological time recorded in rock could, for example, be identified in sediments deposited half a world away in the middle of the Pacific Ocean by virtue of the presence of these characteristic microscopic fossils. Because the Jurassic and Cretaceous deep-sea pelagic sediments in the Pacific and other oceans could only be sampled by drilling, with the subsequent recovery of very limited core material, the chances of encountering stratigraphically useful ammonites was slim, whereas microscopic fossils usually proved abundant enough in many places to give an accurate age determination. Such studies opened the door for 
examination of chemical and biological signals recorded at the same time in different parts of the world ocean. Investigation of such phenomena that seemingly have affected marine waters across the globe has given rise to the discipline of palaeoceanography.

\subsection{Cyclostratigraphy and orbital chronology}

The Cretaceous pelagic sediments of particularly the Umbria-Marche region have been crucial to studies on cyclicity, typically manifested by regular stratigraphic alternations in colour (grey, green, black or red), hardness and degree of weathering, all of which may relate to variations in the ratio of clays to calcium carbonate as well as the content of iron minerals and organic matter $[9,10,11,12]$. At the outcrop level, different beds are commonly bundled or packaged into larger units, manifesting an obvious hierarchy in the stratigraphic pattern. These cycles are now routinely interpreted as related to the parameters of the Earth's orbit that govern the latitudinal distribution and intensity of solar radiation received at the planetary surface and hence control climate. Major effects on the continents would have involved changes in temperature and rainfall affecting the volume and content of fluvial input to marine environments, whereas the oceans themselves would have responded to changes to wind-driven lateral and vertical movements of watermasses, in some cases bringing nutrient-laden seawater close to the surface where it could be utilized by photosynthetic plankton.

The frequency of precession (very approximately $20 \mathrm{kyr}$ ), obliquity (very approximately $40 \mathrm{kyr}$ ) and eccentricity (very approximately 100 and $\sim 400 \mathrm{kyr}$ as major parameters) may all be recognized in favourable sections, with varying degrees of confidence, potentially producing a rock-based chronometer that can be integrated with biostratigraphy and magnetostratigraphy to identify ever-smaller increments of geological time.

\subsection{Deep- and shallow-water sediments}

The Jurassic and Cretaceous sediments, typically rich in calcium carbonate, which contain the micro- and macrofossils of stratigraphic worth in Italy, are pelagic in character and conventionally interpreted as deposited on an ancient sunken continental margin at the edge of an ocean in water depths estimated as hundreds to a few thousand metres 
$[13,14,15]$. However, in many places stratigraphically underlying these pelagic sediments are limestones of a different character: they are typically light-coloured, devoid of ammonites and planktonic microfossils, particularly hard-weathering, and thereby form some of the spectacular mountain scenery found in the Dolomites, Southern Alps, Apennines and Sicily. Although these white to pale grey limestones contain some fossils, which are always difficult to extract, these faunas do not supply the stratigraphic refinement offered by the organisms found in the overlying pelagic sediments, but we know that some sections date to the Triassic and Jurassic. The application of magnetostratigraphy and cyclostratigraphy has proven problematic with these sedimentary rocks because they appear to have been deposited discontinuously and hence contain unrecorded time, thereby possessing an incomplete record. The different types of grains and sedimentary structures found in these calcareous deposits do, however, point to formation in very shallow warm water, at depths of a few tens of metres or less. A modern analogue for such environments would be found in the tropical Bahama Banks, on the eastern continental margin of North America [13, 14].

\subsection{Stable isotopes and chemostratigraphy}

An additional aid to dating and correlation, which has become progressively more important since 1980, and applicable to both deep- and shallow-water Mesozoic limestones, lies in the field of geochemistry, namely the development of chemostratigraphy. Most important in this context have been the stable isotopes of carbon, oxygen, sulphur and strontium and their application has now become commonplace. In terms of investigations of environmental change in the deep past, carbon-isotope signatures (to be exact, the ratio between carbon-13 and carbon-12 plotted against sections of sedimentary rock) have proved to be particularly useful on two accounts $[16,17,18]$. Firstly, their rapid change in values through time has produced distinctive patterns that plotted against sedimentary sections have enabled correlation of sedimentary sequences around the globe, both in pelagic and shallow-water sediment; and secondly, the apparently rapid movement to higher or lower values points to major disturbances to the global carbon cycle with impacts on phenomena such as temperature, dissolved oxygen levels in marine waters and ocean acidification $[19,20]$. 


\subsection{Hyperthermals and Oceanic Anoxic Events}

As the reality of global warming has become widely accepted, it has become important and potentially illuminating to look back in geological time to investigate the causes and consequences of past extreme temperatures in the oceans and atmosphere. Here again, the sedimentary sequences exposed in Italy, of both deep- (pelagic) and shallowwater character, offer an exemplary archive with evidence of so-called 'hyperthermals' recorded in a number of exposures. Although the reconstruction of ancient seawater temperatures relies on sophisticated analytical work, typically involving determination of oxygen isotopes (the ratio between oxygen-18 and oxygen-16) in limestones and fossils made of the mineral calcite, and characterization of complex organic molecules in bulk sediment, many outcrops in Italy and elsewhere in the world show changes in lithology that date to these times of extreme global warmth.

The most dramatic manifestation of this phenomenon, in terms of abrupt lithological change, is the 1-metre-thick organic-rich black shale intercalated between the white pelagic limestone of the Scaglia that was first described by Guido Bonarelli [21] in a river valley cutting through the mountains outside Gubbio in Marche-Umbria [15]. Deposited some 94 million years ago in the Late Cretaceous, the so-called Livello Bonarelli coincided in time with extremely high global sea-surface temperatures that seemingly well exceeded $35^{\circ} \mathrm{C}$ in low latitudes [22]. The peculiar characteristics of this unit, being unusually enriched in organic matter (that imparts the black colour), as well as the remains of siliceous zooplankton known as radiolaria and tiny crystals of pyrite, suggest deposition in an oxygen-depleted environment under conditions of high plankton productivity in near-surface waters. A very similar deposit, of comparable thickness, named the Livello Selli, has also been described from Marche-Umbria and this unit dates to 120 million years ago, similarly corresponding in time with a hyperthermal [22, $23,24]$. Such sediments have been attributed to globally significant phenomena known as Oceanic Anoxic Events that are associated with high rates of speciation and extinction of planktonic organisms $[19,25$, 26, 27, 28, 29].

One of the principal factors favouring accumulation of organic matter on the sea floor was decreased oxygen solubility due to elevated marine temperatures. The additional factor was high plankton produc- 
tivity, the source of much organic matter that transits to the sea floor, the origin of which can be directly attributed to elevated nutrient availability. Supply of these nutrients can be related to increased weathering on the continents with transport by expanded rivers to the ocean together with accelerated reaction between sea-floor basalts and seawater: all processes that became progressively more important under conditions of extreme global warming [30, 31, 32, 33].

\subsection{Role of Large Igneous Provinces}

The reaction between sea-floor basalts and seawater may have been particularly important because of the well-established coincidence in timing of submarine extrusion of huge volumes of this type of volcanic rock (to form so-called Large Igneous Provinces) in the oceans and the development of hyperthermals, commonly associated with regional oxygen depletion in the oceans. Chemical fingerprints in Cretaceous black shales, such as the Livello Bonarelli, Livello Selli and their correlatives elsewhere in the world, indicate contemporaneous magmatic activity $[34,35,36,37]$. Such relationships have offered the possibility that hyperthermals and/or oceanic anoxic events owe their ultimate cause to a volcanogenic supply of carbon dioxide [e.g., 30, 31, 32]. Here again, the Livello Bonarelli has something to teach us in that, despite being underlain and overlain by pelagic limestones, the black shale itself is totally devoid of calcium carbonate, a characteristic that could well have been caused by ocean acidification related to heightened atmospheric levels of this greenhouse gas $[20,38]$.

\subsection{Feedbacks in the ocean-atmosphere system}

Recently, various feedbacks in the ocean-atmosphere system have been recognized in that increased weathering of silicate rocks on land and under the sea, for which there is geochemical evidence, and deposition of organic matter in black shales, are both processes that will draw down carbon dioxide and promote global cooling through an inverse greenhouse effect [39]. Indeed, such transient cooling phases have now been recognized as punctuating hyperthermals/oceanic anoxic events from the Cretaceous sedimentary record in Italy and elsewhere $[40,41]$. The overall atmospheric response during these episodes of intense environmental change must therefore have been the 
result of a competition between rates of supply of volcanogenic carbon dioxide and its loss to chemical and biological processes operating in the oceans and on the continents. An interesting effect of a global increase in organic-matter burial, all other factors being equal, would have been a rise in the oxygen content of the atmosphere, which would have caused shallow levels of the ocean, well above the deeper anoxic layers, to remain well ventilated. Investigation of phenomena such as these belongs in the realm of 'Earth System Science'.

\section{CONCLUSiOnS}

Our present-day understanding of the physical, chemical and biological processes that affected the oceans and atmosphere during the Mesozoic Era, when the planet was largely if not wholly without polar ice, has been built on the development of sound stratigraphy. The combination of availability of excellent outcrops of limestones and shales in mountains and streams, extending from the Alps to Sicily, coupled with the strong tradition for all branches of palaeontology in Italian universities, has underpinned the new disciplines of palaeoceanography and Earth-System Science, particularly as applied to the greenhouse world of the deep past.

\section{ACKNOWLEDGEMENTS}

I am very grateful to Elisabetta Erba for her help with the Italian abstract. 


\section{REFERENCES}

1. Arkell WJ, Jurassic Geology of the World. Oliver and Boyd, Edinburgh, 806 pp, 1956.

2. Renz, O, Stratigraphische und mikropalaeontologische Untersuchung der Scaglia (Obere Kreide-Tertiär) im zentralen Apennin, Eclogae Geologicae Helvetiae, 1936: 29: 1-149.

3. Premoli Silva I, Sliter WV, Cretaceous planktonic foraminiferal biostratigraphy and evolutionary trends from the Bottaccione section, Gubbio, Italy, Palaeontographia italica, 1994: 82: 1-89.

4. Erba E, Calcareous nannofossils and Mesozoic oceanic anoxic events, Marine micropaleontology, 2004: 52: 85-106.

5. Erba E, Bottini C, Faucher G, Gambacorta G, Visentin S, The response of calcareous nannoplankton to Oceanic Anoxic Events: The Italian pelagic record, Bollettino della Società Paleontologica Italiana, 2019: 58: 51-71.

6. Lowrie W, Alvarez W, Upper Cretaceous-Paleocene magnetic stratigraphy at Gubbio, Italy III. Upper Cretaceous magnetic stratigraphy, Geological Society of America Bulletin, 1977: 88: 374-377.

7. Alvarez W, Arthur MA, Fischer AG, Lowrie W, Napoleone G, Premoli Silva I, Roggenthen WM, Upper Cretaceous-Paleocene magnetic stratigraphy at Gubbio, Italy V. Type section for the Late Cretaceous-Paleocene geomagnetic reversal time scale, Geological Society of America Bulletin, 1977: 88: 383-389.

8. Coccioni R, Premoli Silva I, Revised Upper Albian-Maastrichtian planktonic foraminiferal biostratigraphy and magneto-stratigraphy of the classical Tethyan Gubbio section (Italy), Newsletters on Stratigraphy, 2015: 48: 47-90.

9. De Boer PL, Cyclicity and storage of organic matter in Middle Cretaceous pelagic sediment, in Cyclic and Event Stratification, Einsele G, Seilacher, A, editors, 456474, Springer Verlag, New York, 1982.

10. Herbert TD, Fischer AG, Milankovitch climatic origin of mid-Cretaceous black shale rhythms in central Italy: Nature, 1986: 321: 739-743.

11. Fischer AG, D’Argenio B, Premoli Silva I, Weissert H, Ferreri V, Cyclostratigraphic approach to Earth's history: an introduction, in Cyclostratigraphy: Approaches and Case Histories, D'Argenio B, Fischer AG, Premoli Silva I, Weissert H, editors, Special Publication of the Society of economic Paleontologists and Mineralogists: 81: 5-13, 2004.

12. Fischer AG, Hilgen, FJ, Garrison RE, Mediterranean contributions to cyclostratigraphy and astrochronology, Sedimentology, 2009: 56: 63-94.

13. Bernoulli D, North Atlantic and Mediterranean Mesozoic facies: a comparison, in, Initial Reports of the Deep Sea Drilling Project ,11, Hollister CD, Ewing JI et al., 801-871, US Government Printing Office, Washington, DC, 1972.

14. Bernoulli D, Jenkyns HC, Alpine, Mediterranean and Central Atlantic Mesozoic facies in relation to the early evolution of the Tethys, in Modern and Ancient Geosynclinal Sedimentation, a Symposium, Dott RH, Shaver RH, editors, Special Publication of the Society of Economic Paleontologists and Mineralogists: 19: 129160, 1974.

15. Bernoulli D, Jenkyns HC, Ancient oceans and continental margins of the Alpine- 
mediterranean Tethys: deciphering clues from Mesozoic pelagic sediments and ophiolites, Sedimentology, 2009: 56: 147-190.

16. Scholle PA, Arthur MA, Carbon isotope fluctuations in Cretaceous pelagic limestones: potential stratigraphic and petroleum exploration tool, American Association of Petroleum Geologists Bulletin, 1980: 64: 67-87.

17. Jenkyns HC, Clayton CJ, Black shales and carbon isotopes in pelagic sediments from the Tethyan Lower Jurassic, Sedimentology, 1986: 33: 87-106.

18. Gambacorta G, Jenkyns HC, Russo F, Tsikos H, Wilson PA, Faucher G, Erba E, Carbon-and oxygen-isotope records of mid-Cretaceous Tethyan pelagic sequences from the Umbria-Marche and Belluno Basins (Italy), Newsletters on Stratigraphy, 2015: 48: 299-323.

19. Jenkyns HC, Geochemistry of oceanic anoxic events, Geochemistry Geophysics Geosystems, 2010: 11: Q03004, doi: 10.1029/2009GC002788.

20. Jenkyns HC, Oceanic Anoxic Events: the record from Italy and beyond, Rendiconti Online della Società Geologica Italiana, 2012: 21: 8-10.

21. Bonarelli G, Il territorio di Gubbio. Notizie geologiche. Tipografia economica, Roma, 38 pp, 1891.

22. O’Brien CL, Robinson SA, Pancost RD, Sinninghe Damsté JS, Schouten S, Lunt DJ, Alsenz H, Bornemann A, Bottini C, Brassell SC, Farnsworth A, Forster A, Huber BT, Inglis GN, Jenkyns HC, Linnert C, Littler K, Markwick P, McAnena A, Mutterlose J, Naafs BDA, Püttmann W, Sluijs A, van Helmond AGM, Vellecoop J, Wagner T, Wrobel N E, Cretaceous sea-surface temperature evolution: Constraints from $\mathrm{TEX}_{86}$ and planktonic foraminiferal oxygen isotopes, Earth-Science Reviews, 2017: 172: 224-247.

23. Coccioni A, Nesci O, Tramontana M, Wezel FC, Moretti E, Descrizione di un livello-guida "radiolaritico-bituminoso ittiolitico" alla base delle Marne a fucoidi nell'Appennino umbro-marchigiano, Bollettino della Società Geologica Italiana, 1987: 106: 183-192.

24. Malinverno, A, Hildebrandt J, Tominaga M, Channell, JET, M-sequence geomagnetic polarity time scale (MHTC12) that steadies global spreading rates and incorporates astrochronology constraints, Journal of Geophysical Research, 2012: 117: B06104, doi:10.1029/2012JB009260.

25. Schlanger SO, Jenkyns HC, Cretaceous oceanic anoxic events: causes and consequences, Geologie en Mijnbouw, 1976: 55: 179-194.

26. Jenkyns HC, Cretaceous anoxic events: from continents to oceans. Journal of the Geological Society of London, 1980: 137: 171-188.

27. Premoli Silva I, Erba E, Salvini G, Locatelli C, Verga D, Biotic changes in Cretaceous oceanic anoxic events of the Tethys. Journal of Foraminiferal Research, 1999: 29: 352-370.

28. Leckie RM, Bralower TJ, Cashman R, Oceanic anoxic events and plankton evolution: Biotic response to tectonic forcing during the mid Cretaceous. Paleoceanography, 2002: 17/3: doi: 10.1029/2001PA000623.

29. Tsikos H, Jenkyns HC, Walsworth-Bell B, Petrizzo MR, Forster A, Kolonic S, Erba E, Premoli Silva I, Baas M, Wagner T, Sinninghe Damsté JS, Carbon-isotope stratigraphy recorded by the Cenomanian-Turonian Oceanic Anoxic Event: correlation 
and implications based on three key localities. Journal of the Geological Society of London, 2004: 161: 711-719.

30. Jenkyns HC, Mesozoic anoxic events and palaeoclimate, Zentralblatt für Geologie und Paläontologie, 1999: 1997: 943-949.

31. Jenkyns HC, Evidence for rapid climate change in the Mesozoic-Paleogene greenhouse world. Philosophical Transactions of the Royal Society, Series A, 2003: 361: 1885-1916.

32. Erba E, Duncan RA, Bottini C, Tiraboschi D, Weissert H, Jenkyns HC, Malinverno A, Environmental consequences of Ontong Java Plateau and Kerquelen Plateau volcanism, in: The Origin, Evolution, and environmental Consequences of oceanic Large Igneous Provinces, Neal CR, Sager, WW, Sano T, Erba E, editors, Geological Society of America Special Paper: 511: 271-303, 2015.

33. Jenkyns HC, Dickson AJ, Ruhl M, van den Boorn SHJM, Basalt-seawater interaction, the Plenus Cold Event, enhanced weathering and geochemical change: deconstructing Oceanic Anoxic Event 2 (Cenomanian-Turonian, Late Cretaceous), Sedimentology, 2017: 64: 16-43.

34. Turgeon SC, Creaser RA, Cretaceous oceanic anoxic event 2 triggered by a massive magmatic episode, Nature, 2008: 454: 323-326.

35. Du Vivier AD, Selby D, Sageman BB, Jarvis I, Gröcke DR, Voigt S, Marine ${ }^{187} \mathrm{Os} /{ }^{188} \mathrm{Os}$ isotope stratigraphy reveals the interaction of volcanism and ocean circulation during Oceanic Anoxic Event 2. Earth and Planetary Science Letters, 2014: 389: 23-33.

36. Charbonnier G, Föllmi KB, Mercury enrichments in lower Aptian sediments support the link between Ontong Java large igneous province activity and oceanic anoxic episode 1a. Geology, 2017: 45: 63-66.

37. Scaife JD, Ruhl M, Dickson AJ, Mather TA, Jenkyns HC, Percival LME, Hesselbo SP, Cartwright J, Eldrett JS, Bergman SC, Minisini D, Sedimentary mercury enrichments as a marker for submarine large igneous province volcanism? Evidence from the Mid Cenomanian event and Oceanic Anoxic Event 2 (Late Cretaceous). Geochemistry, Geophysics, Geosystems, 2017: 18: 4253-4275.

38. Hönisch B, Ridgwell A, Schmidt DN, Thomas E, Gibbs SJ, Sluijs A, Zeebe R, Kump L, Martindale RC, Greene SE, Kiessling W, Ries J, Zachos JC, Royer DL, Barker S, Marchitto TM Jr, Moyer R, Pelejero C, Ziveri P, Foster GL, Williams B, The geological record of ocean acidification. Science, 2012: 335: 1058-1063.

39. Pogge von Strandmann PA, Jenkyns HC, Woodfine RG, Lithium isotope evidence for enhanced weathering during Oceanic Anoxic Event 2. Nature Geoscience, 2013: 6: 668-672.

40. Jenkyns HC, Transient cooling episodes during Cretaceous Oceanic Anoxic Events with special reference to OAE 1a (Early Aptian). Phil. Trans. R. Soc., Series A, 2018: 376: 20170073, doi: 10.1098/rsta.2017.0073.

41. O'Connor LK, Jenkyns HC, Robinson SA, Remmelzwaal SR, Batenburg SJ, Parkinson IJ, Gale AS, A re evaluation of the Plenus Cold Event, and the links between $\mathrm{CO}_{2}$, temperature, and seawater chemistry during OAE 2. Paleoceanography and Paleoclimatology, 2020: 35: e2019PA003631, doi: 10.1029/2019PA003631. 
